\title{
ロボットの障害物回避行動生成における 画像特徵の獲得
}

\author{
岡 本太
}

\section{Acquisition of Image Feature on Collision for Robot Motion Generation}

\author{
Taichi Okamoto*1, Yuichi Kobayashi ${ }^{* 2 * 3}$ and Masaki Onishi ${ }^{* 3 * 4}$
}

\begin{abstract}
It is important for robots that act in human-centered environments to build image processing in a bottom-up manner. This paper proposes a method to autonomously acquire image feature extraction that is suitable for motion generation while moving in unknown environment. The proposed method extracts low level features without specifying image processing for robot body and obstacles. The position of body is acquired in image by clustering of SIFT features with motion information and state transition model is generated. Based on a learning model of adaptive addition of state transition model, collision relevant features are detected. Features that emerge when the robot can not move are acquired as collision relevant features. The proposed framework is evaluated with real images of the manipulator and an obstacle in obstacle avoidance.
\end{abstract}

Key Words: Feature Extraction, Robot Motion Learning, Obstacle Avoidance

\section{1.はじめに}

これまで，工場に限定されていたロボットの活躍のフィールド は人間社会へと広がりを見せている，人間社会で活躍するロボッ 卜を目指した視覚認識処理としては, 注視物体 (対象物, 障害物 など）の三次元形状モデルを用いる方法が一般的であり [1], 三 次元形状モデルを用いたロボットの動作生成の研究が数多くさ れている [2] [3]. 三次元形状だけでなく対象の物理特性など様々 な設計知識を埋め込んだ認識・制御技術は，多様に変化する実 世界で活躍できるロボットを実現するための有望なアプローチ の一つであるが，現時点ではその枠組みでシンボル接地問題 [4] をはじめとする様々な問題を解決可能であるという確証を得る には至っていない.

一方，設計者が事前に与える知識をできるだけ少なくしてロ ボット自身に様々な情報を獲得させるアプローチも盛んに研究 されている [5] [6]. そのなかで認識プロセスを獲得させるアプ

原稿受付 2009 年 10 月 9 日

*1 (株) オ八ラ

$* 2$ 東京農工大学

*3 理化学研究所 理研一東海ゴム人間共存ロボット連携センター

*4 产業技術総合研究所

${ }^{* 1}$ Ohara Inc.

${ }^{* 2}$ Tokyo University of Agriculture and Technology

${ }^{* 3}$ RIKEN, RIKEN-TRI Collaboration Center for Human-Interactive Robot Research (RTC)

${ }^{* 4}$ National Institute of Advanced Industrial Science and Technology (AIST)

口本論文は提案性で評価されました。
ローチは，問題に特化した設計によらずにロボット自身の試行 錯誤から認識・行動を実現することが期待されている。しかし, どの程度の知識をあらかじめ埋め込むのが柔軟なロボットシス テムを構築するのに最善かという問題には，現時点では明確な 答えは出ていない，その意味でも既存の設計知識を前提としな い学習方法を様々な角度から考えることには, 意義があると考 えられる。

以上のことを背景として, ロボットの知能の発達において自 らの運動に基づいて視覚入力の特徵抽出器を生成する能力が重 要であるとする立場から, Minato らはロボットが自律的に画 像処理フィル夕を獲得する手法を提案した [7]. この研究では, 画像入力と行動により定義されたエントロピーを最大化するこ とによって，画像処理フィル夕を自律的に獲得しているが, 望 ましい行動は教師信号として与えられている. 特徴抽出学習に おいてあらかじめ望ましい動作を与えるのではなく適切な動作 を生成する過程と結びつけて考えることにより，ロボットの学 習能力の向上が期待される.

動作の教示とは別の方法で, 運動との関係から視覚情報の抽 出を扱う研究もある. Fitzpatrick らは, 自己の身体像と対象物 をボトムアップに獲得する手法を提案している $[8]$. この研究で は, 画像内で最初に動いた物体をロボットの腕と認識し, 対象 物をロボットアームで押し操作する。この押し操作によって対 象物は移動し，差分法を用いることで対象物が抽出可能である。 しかし，押し方に対する対象物の動き方という瞬間的な関倸は 学習しているが, 獲得した身体像を用いた運動学の学習には適 用されていない。 また, Stoytchevは TV 上での身体の位置を 
発見し，異なるスケール間の画像の同次変換を獲得する手法を 提案しており, ロボットアームにマーカーを付け, 運動指令を 出したときに画像上で動いたものを身体として扱っている [9]. この手法は画像の回転や拡大にも適用できるが，マーカーを付 けて身体を抽出しやすくしているため抽出対象に特化している. これらの研究 [8] [9] では身体像の獲得を行っているが, 行動生 成への適用が十分に論じられていない. また差分などのシンプ ルな処理だけでなく, より低次の視覚特徵を動作生成と関係さ せながらボトムアップに学習することができれば，より適用範 囲の広い画像処理法の構築につながることが期待できる.

一方, 行動学習・生成の立場から自律的に状態の識別を行う ことを目指した研究も行われている. McCallum は, 観測と行 動の履歴を木構造で表現することにより, 部分観測マルコフ決 定過程での行動学習法 [10] や観測特徵の選択法 [11] を提案し た。また, Ishiguro らは, 報酬情報の統計的な判別による状態 の階層的線形分離法を提案している $[12]$. これらのように報酬 情報を手がかりに状態の識別を行う方法のほかに, 状態遷移の 情報を用いた方法の例として, 高橋らは状態遷移と報酬を予測 する局所モデルを用いた状態の分割法を提案している [13]. 状 態の離散化ではなく状態予測モデル自体を切り替えるアプロー チとしては, 複数の運動認識・制御モジュールを切り替える運 動生成法（MOdule Selection And Identification for Control; MOSAIC) が知られており [14] [15], その強化学習への拡張も 提案されている $[16]$. しかし, これらの研究では, 身体像獲得 の研究で用いられてきた「運動指令と観測情報が同時に起こる （同起する）という情報から身体を抽出する」という考え方は用 いられておらず，報酬や状態遷移情報のみを用いて数多く抽出 された画像特徴の選択を行うことは容易ではない.

そこで本研究では, 身体像獲得の研究で用いられてきた「運 動指令と観測情報の同起」という考え方を基礎にした，運動生 成と特徴の抽出・識別を扱える方法を提案し, 障害物に関する 明示的な知識を埋め达まずに障害物回避行動の生成が可能であ ることを示す，具体的には，画像から行動生成のために必要な 低次元視覚特徵をボトムアップに獲得し，2 関節マニピュレータ の障害物回避行動を行うという具体的な行動学習問題を例にと り, 行動学習の枠組みに視覚特徵学習を取り入れた形での動作 生成を提案する。特徵抽出にはSIFT (Scale Invariant Feature Transform）を用いる. SIFT とは, Loweによって提案された 画像中に存在する特徴を記述する手法の一つである [17]. SIFT は, 回転・スケール変化等に不変な特徵量を記述するため, イ メージモザイク等の画像のマッチングや物体認識に用いられる 代表的な画像特徵量である。ロボットビジョンへの適用例とし ては，Asfour らによるSIFT を用いたロボットによる物体認 識 [18], Chavez らによるソナーセンサと SIFT を組み合わせ たロボットの経路計画 [19] などが挙げられる.

この SIFT 特徴を用いて, マニピュレータの色や形状などの 事前知識を必要としないマニピュレータの身体特徴, 身体の状態 遷移予測モデル, さらに行動に必要な画像特徵を自律的に抽出

\footnotetext{
†実際のマニピュレータは連続的に運動するため, 衝突時に格子点上の関 節角度をとるとは限らない。その場合は衝突により動けないと判断した ときに元の格子点に戻るものとする.
}

する手法を提案する．提案手法は身体の形状，色などに左右され ない動き情報との相関関係を用いた身体抽出を行うことで, 異 なるマニピュレータにも適用することができる。ささに文献 [15] のような複数の状態遷移予測モデルを, 画像特徵の認識に拡張 したモデルを提案する．障害物などの物体を認識するには，物 体は背景よりも視覚注意を引きやすいため, saliency map [20] などが広く用いられる.しかし, 本研究では障害物そのものを 認識するのではなく, 状態遷移予測モデルの切り替えという枠 組みのもとで衝突に関係する特徵を選択するという方法をとる. また, 動作生成には強化学習を用いる $[21]$.これにより, ロボッ トの運動学や形状モデル, 環境のモデルに基づいたコンフィグ レーション空間での動作生成 [22] と異なり, それらの情報を用 いずに試行錯誤を通じて環境に適した行動を獲得することがで きる。

以下では, 2 章で本研究の問題設定を説明する。 3 章で本研 究の提案手法を述べ, 4 章に実験結果を示す. 5 章で今後の課題 を述べ, 6 章でまとめる.

\section{2. 問 題 設 定}

本研究では 2 関節マニピュレータとカメラからなるロボット システムを考え, カメラからの画像を用いてマニピュレータを 制御する. カメラは固定してあり, マニピュレータはカメラ光 軸の垂直面内の二次元空間を運動するものとする. また，マニ ピュレータ以外に画像中で動くものはないと仮定する. 本ロボッ トシステムに二つのタスクを設定する。一つ目は, 身体（マニ ピュレータ）の一部を二次元画像中の目標位置に動かすことで あり, マニピュレータの画像上での形状, 色, 大きさ, 位置は事 前に与えないものとする，二つ目は，障害物を避けながら身体 の一部を目標位置まで動かすことであり, 障害物の画像上での 形状, 色, 大きさ, 位置も事前に与えないものとする. 画像中に 映る物体の情報は与えないが，目標位置は既知として与えてい る. マニピュレータへの運動指令は関節角 $\boldsymbol{q}=\left[q_{1}, q_{2}\right]^{T} \in \mathbb{R}^{2}$ の微小変化 $\Delta \boldsymbol{q}=\left[\Delta q_{1}, \Delta q_{2}\right]^{T}$ とし, 各関節は位置制御される ものとする.すなわち, マニピュレータの関節角度は $\left(q_{1}, q_{2}\right)$ の離散格子点上を遷移する。障害物に衝突した時は, マニピュ レータは動かないため現在の格子点上にとどまる†。また，マニ ピュレータがオクルージョンにより見えなくなることはないも のとする。

\section{3. 障害物回避行動における画像特徵の選択}

本提案手法は大きくわけて以下の四つのステップからなる.

第 1 ステップ：身体特徵の抽出

第 2 ステップ: 状態遷移予測モデルの生成

第 3 ステップ: 衝突特徴の選択

第 4 ステップ：動作生成

まず，障害物との衝突がない状況で身体抽出を行う（第 1 ス テップ). 本研究では，マニピュレータの関節を変位させたとき の画像上の動き情報を用いることで身体を抽出する。動き情報 の獲得には, SIFT の対応点探索 [17] を用いる. 回転・スケール 変化等にロバストな特徵点同士のマッチングが取れる特徵抽出 手法の代表的な手法の一つとして, 本研究では SIFT を用いる. 
SIFT の処理はキーポイントの検出と特徵量の記述の 2 段階 からなる. キーポイントは, スケールの異なるガウス関数と入力 画像を畳み込んだ平滑化画像の差分 (Difference of Gaussian; DoG 画像) の極值により検出される. 次に, 検出したキーポイ ントに対してオリエンテーションを求める.オリエンテーション はキーポイントにおける方向を表し, 特徴量記述の際にオリエ ンテーションによる向きの正規化を行うことで SIFT 特徵量は 回転に不変になる。求めたオリエンテーションをもとに, SIFT descriptorにより 128 次元の特徵量を記述する. そのキーポイ ントが持つスケールを半径とした領域を, 一辺につき 4 ブロッ クの計 16 ブロックに分割し，ブロックごとに 8 方向 (45 [deg] ずつ）の勾配方向ヒストグラムを生成する. $4 \times 4=16$ ブロッ クの各 8 方向のヒストグラムを作成するため, $4 \times 4 \times 8=128$ 次元の特徵ベクトルとしてキーポイントの特徵を記述する.

以降, 特徵点は SIFT 特徵量のキーポイントを表す.そして, 身体の動き情報を用いてヤコビ行列を求めることにより，マニ ピュレータの状態遷移予測モデルを生成する（第 2 ステップ）.

次に, 障害物との衝突が生じる状況で衝突特徴の選択を行う (第 3 ステップ). 障害物回避行動の実現のためには, 一般的に は障害物の位置・形状を知る必要があるが, 本研究では障害物 そのものを抽出するのではなく, 障害物との衝突を表す特徴を 選択する。さらに，選択された障害物との衝突を表す特徴を用 いて, 障害物回避行動を行う. 動作生成には強化学習の一つで ある動的計画法を用いる(第 4 ステップ). 以下でそれぞれの処 理について詳しく述べる.

\section{1 身体特徵の抽出}

マニピュレータに運動指令を出したときに，二次元画像中で 最も大きく動いている身体部分の特徵点を身体を表す特徴点と して抽出する．ここでは衝突のない動きを考える．基準となる 姿勢と, そこから関節角度を変化させた姿勢の二つの画像を用 いて, SIFTによる対応点探索を行う. 各特徴点は画像中の二 次元位置ベクトルと, SIFT descriptor による 128 次元の特徵 ベクトルで表される。異なる画像間での特徴点の特徵べクトル のユークリッド距離を用いて対応の判別を行う.

運動指令を出す前の時刻 $t$ の画像を $I(t)$, 運動指令を出した 後の画像を $I(t+\Delta t)$ とする. 画像 $I(t)$ 上の $i$ 番目の特徵点 の特徵べクトルを $\boldsymbol{a}_{i}^{I(t)} \in \mathbb{R}^{128}$, 画像 $I(t+\Delta t)$ 上の $j$ 番目の 特徽点の特徵べクトルを $\boldsymbol{a}_{j}^{I(t+\Delta t)} \in \mathbb{R}^{128}$ と定義し, 対応点探 索を行う. ここで, $i=1,2, \cdots, n^{I(t)}, j=1,2, \cdots, n^{I(t+\Delta t)}$ であり, $n^{I}$ は画像 $I$ 中の特徵量の数を表す。それぞれの画像 中の特徴点間の特徵ベクトルのユークリッド距離 $d$ は次式によ り算出される.

$$
d=\left\|\boldsymbol{a}_{j}^{I(t+\Delta t)}-\boldsymbol{a}_{i}^{I(t)}\right\|=\sqrt{\sum_{k=1}^{128}\left(a_{j k}^{I(t+\Delta t)}-a_{i k}^{I(t)}\right)^{2}}
$$

ここで $a_{i k}^{I(t)}$ は $i$ 番目の特徴べクトルの $k$ 番目の要素を表す. 画像 $I(t+\Delta t)$ 中のある特徵点 1 点に対して, 画像 $I(t)$ 中の 全特徽点とのユークリッド距離 $d$ を算出し, その中で最も $d$ が 最小となる特徵点同士を対応点として検出する。 ただし, 対応

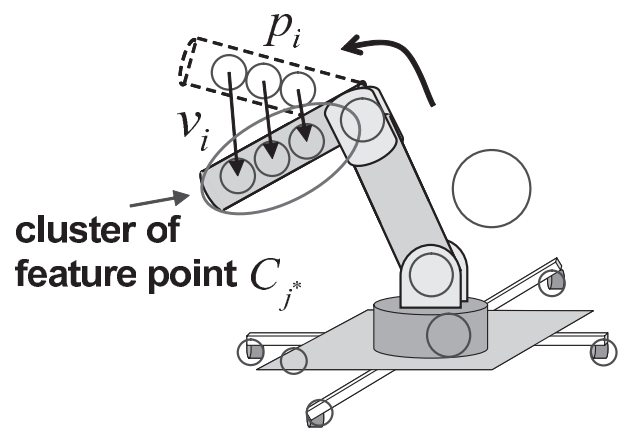

Fig. 1 Outline of clustering to extract body relevant features

点とのユークリッド距離が閾值 $\varepsilon$ より大きい場合には, 未対応 特徵集合を $A$ とし, 以下のようにその特徵点を記憶する.

$$
\begin{array}{r}
A \leftarrow A \cup\left\{\boldsymbol{a}_{j}^{I(t+\Delta t)} \mid\left\|\boldsymbol{a}_{j}^{I(t+\Delta t)}-\boldsymbol{a}_{i}^{I(t)}\right\|>\varepsilon,\right. \\
\left.i=1,2, \cdots, n^{I(t)}\right\}
\end{array}
$$

それぞれの画像で対応の取れた $n$ 個の特徵点の画像座標系で の位置を $\boldsymbol{p}_{i}(t) \in \mathbb{R}^{2}, \boldsymbol{p}_{i}(t+\Delta t) \in \mathbb{R}^{2}(i=1,2, \cdots, n)$ とす ると, $i$ 番目の特徵点の変位量 $\boldsymbol{v}_{i}$ は,

$$
\boldsymbol{v}_{i}=\boldsymbol{p}_{i}(t+\Delta t)-\boldsymbol{p}_{i}(t), \quad i=1,2, \cdots, n
$$

と表せる. 次に特徵の変位量 $\boldsymbol{v}_{i}$ と位置 $\boldsymbol{p}_{i}$ の四次元べクトル $\left[\boldsymbol{v}_{i}^{T}, \boldsymbol{p}_{i}^{T}\right]^{T} \in \mathbb{R}^{4}$ を用いて mean shift [23] によるクラスタリン グを行う. 身体以外に動いているものは存在しないという仮定 より，次式によって最も大きな変位量 $\boldsymbol{v}_{i}$ を持つクラスタを身 体の特徵点とする.

$$
j^{*}=\underset{j}{\operatorname{argmax}} \frac{1}{\left|C_{j}\right|} \sum_{i \in C_{j}}\left\|\boldsymbol{v}_{i}\right\|
$$

ただし $, j=1,2, \cdots, m$ はクラスタ番号を表し,$C_{j}$ は $j$ 番目 のクラスタ（集合）を表す。このクラスタの重心を身体位置とし て扱う. 身体の特徵を抽出するクラスタリングの考えを Fig. 1 に示す. 図中の円が特徵点を表している（円の大きさは特徵点 の持つスケールを表している). マニピュレータを知印方向に動 かしたときの対応点との変位量 $\boldsymbol{v}_{i}$ の大きい部分を身体クラス 夕 $C_{j *}$ とする（楕円で囲まれた特徴点）.

この処理を, 取り得るすべてのパターンの姿勢に対し, マニ ピュレータの二つの関節角度 $\left(q_{1}, q_{2}\right)$ をそれぞれ離散格子点 上の隣接格子 $\left(q_{1}+\Delta q_{1}, q_{2}\right),\left(q_{1}-\Delta q_{1}, q_{2}\right),\left(q_{1}, q_{2}+\Delta q_{2}\right)$, $\left(q_{1}, q_{2}-\Delta q_{2}\right)$ に動かした 4 とおりの変化をさせて行う. 第 1 ステップの処理により, 最も大きく動いている部分として身体 が抽出される。

\section{2 状態遷移予測モデルの生成}

第 2 ステップでは, 第 1 ステップで得られた動き情報（変位 量）を基にヤコビ行列を推定することで, 状態遷移予測モデル を生成する，画像上の身体の特定の部位の位置を $\boldsymbol{x}$ とすると, その速度 $\dot{\boldsymbol{x}}$ と関節角速度 $\dot{\boldsymbol{q}}$ との間には

$$
\dot{\boldsymbol{x}}=\boldsymbol{J}_{q} \dot{\boldsymbol{q}}
$$

という関係がある。ここで $\boldsymbol{J}_{q}$ はヤコビ行列を表す. 関 
節角度 $\boldsymbol{q}$ を同じ姿勢から $\Delta \boldsymbol{q}^{(1)}=\left[\Delta q_{1}, 0\right]^{T}, \Delta \boldsymbol{q}^{(2)}=$ $\left[-\Delta q_{1}, 0\right]^{T}, \Delta \boldsymbol{q}^{(3)}=\left[0, \Delta q_{2}\right]^{T}, \Delta \boldsymbol{q}^{(4)}=\left[0,-\Delta q_{2}\right]^{T}$ の 4 とおりの変位量で変化させる。そのときの画像座標系での 身体位置の変位を $\Delta \boldsymbol{x}^{(1)}, \Delta \boldsymbol{x}^{(2)}, \Delta \boldsymbol{x}^{(3)}, \Delta \boldsymbol{x}^{(4)}$ とする. $\boldsymbol{Q}=$ $\left[\Delta \boldsymbol{q}^{(1)}, \cdots, \Delta \boldsymbol{q}^{(4)}\right], \boldsymbol{X}=\left[\Delta \boldsymbol{x}^{(1)}, \cdots, \Delta \boldsymbol{x}^{(4)}\right]$ とし, ヤコビ行 列 $\boldsymbol{J}_{q}$ は $\boldsymbol{X}=\boldsymbol{J}_{q} \boldsymbol{Q}$ の両辺の二乗誤差を最小にする $\boldsymbol{J}_{q}$ を求 めることで推定する.

$$
\boldsymbol{J}_{q}=\boldsymbol{X} \boldsymbol{Q}^{T}\left\{\left(\boldsymbol{Q} \boldsymbol{Q}^{T}\right)^{-1}\right\}^{T}
$$

このヤコビ行列を, 取り得るすべてのパターンの姿勢ごとに 求める、マニピュレータの状態遷移は推定したヤコビ行列を用 い，以下のように予測できる.

$$
\hat{\boldsymbol{x}}(t+\Delta t)=\boldsymbol{x}(t)+\boldsymbol{J}_{q} \Delta \boldsymbol{q}(t)
$$

第 2 ステップの処理により，運動指令による画像上での身体の 動きの予測モデルを生成することができる。

\section{3 衝突特徴の選択}

第 3 ステップでは, マニピュレータと障害物との衝突を表す のに有効な特徴点を選択する. 衝突特徴の選択には, 第 1 ステッ プと同様にマニピュレータを動かすが，マニピュレータの可動 範囲内に障害物を設置する。障害物が存在しなければ，マニピュ レータは式（7）の予測どおりに遷移する。一方，障害物に衝 突するとマニピュレー夕は予測どおりに遷移せず，現在の格子 点にとどまるという仮定より, 次式のような状態遷移が観測さ れる.

$$
\boldsymbol{x}(t+\Delta t)=\boldsymbol{x}(t)
$$

既存の状態遷移予測モデルでの推定が十分な精度で行えないと きは，新たに状態遷移予測モデルを生成する，また，この状態遷 移予測モデルを選択するために，既存のモデルで推定できない 状況になったときに初めて現われた特徵点を用いる. Fig. 2 の (a) では状態遷移予測モデルどおり動くが，(b)では障害物があ るために状態遷移予測モデルどおりに動かない。このとき現れ た特徴点を衝突特徴としてモデルの切り替えに利用する. Fig. 2 の (b) 中の矢印の指し示す円は対応の取れなかった特徵点を表 し, その他の円が対応の取れた特徵点を表す. Fig. 2 の (b)の 矢印の指し示す円のような, 障害物と接触したときに対応の取 れなかった特徴点を衝突を表す特徴として選択する.

しかし，上記の方法で選択された特徴点の中には衝突の有無 に関係なく，動作前後での対応が取れなかったために検出され た特徴点も存在する. それらを省くため, 衝突特徴を第 1 ステッ プで得られた未対応特徴集合 $A$ の特徴点と比較することで, 衝 突が起きたことによって現れた特徵点かどうかを判断する.未 対応特徴集合と対応の取れない特徴点であれば, 衝突特徴集合 を $C$ とし，以下のように更新する.

$$
\begin{array}{r}
C \leftarrow C \cup\left\{\left.\boldsymbol{a}_{j}^{I(t+\Delta t)}\right|^{\forall} i,\left\|\boldsymbol{a}_{j}^{I(t+\Delta t)}-\boldsymbol{a}_{i}^{I(t)}\right\|>\varepsilon,\right. \\
\left.{ }^{\forall} \boldsymbol{a} \in A,\left\|\boldsymbol{a}_{j}^{I(t+\Delta t)}-\boldsymbol{a}\right\|>\varepsilon\right\}
\end{array}
$$

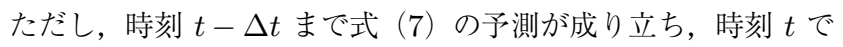
予測誤差が閾值を超えたとする。

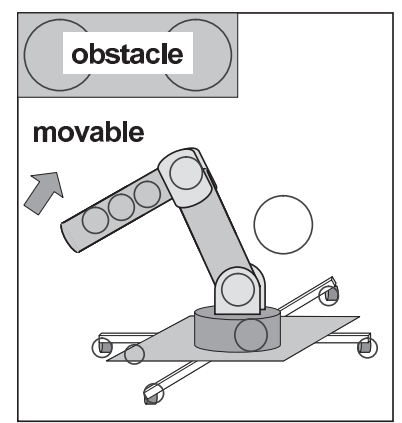

(a) free

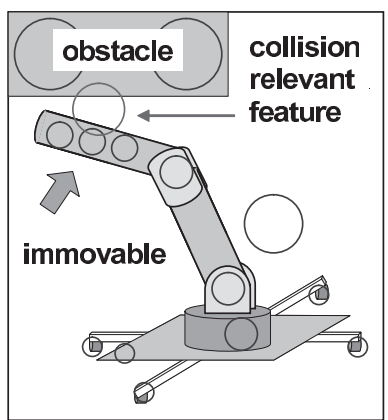

(b) collision
Fig. 2 Outline of acquisition of collision relevant features

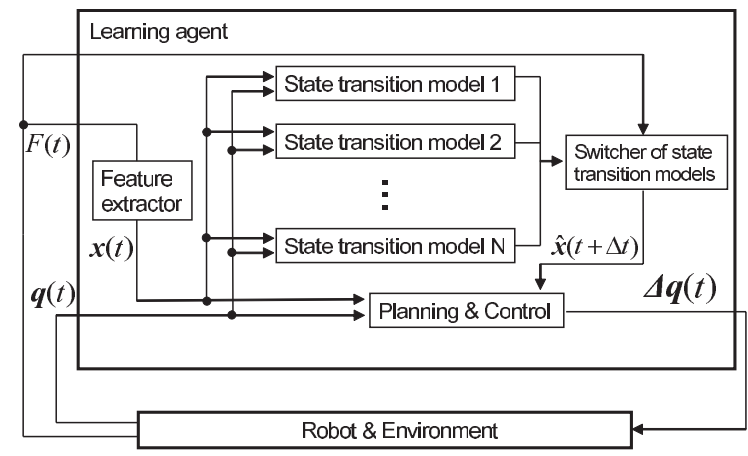

Fig. 3 Selection of state transition model

この特徴点を用いて行動予測モデルの選択を行うことにより， 状況に応じた行動を行うことができる (Fig. 3 参照). 現在の 画像中に現われる画像特徵集合を $F(t)$ として, 以下のように 定義する。

$$
F(t)=\left\{\boldsymbol{a}_{i}^{I(t)} \mid i=1,2, \cdots, n^{I(t)}\right\}
$$

ロボットと環境から関節角度 $\boldsymbol{q}(t)$, 画像特徵集合 $F(t)$ を取り 出し, $F(t)$ の中から身体を表す特徽点を抽出し現在の身体位置 $\boldsymbol{x}(t)$ を得る. $\left\|\boldsymbol{a}_{i}^{I(t)}-\boldsymbol{a}_{j}\right\|<\varepsilon$ により, $\boldsymbol{a}_{j} \in C$ とマッチング の取れる $\boldsymbol{a}_{i}^{I(t)} \in F(t)$ が存在するかどうかで状態遷移予測モデ ルを選択し， 3.4 節で述べる動作生成法により決定される目標 身体位置 $\boldsymbol{x}_{d}$ を求める. $\boldsymbol{x}_{d}$ に最も近づくような関節角の変位 量 $\Delta \boldsymbol{q}(t)$ を算出し, 行動する. 本論文での適用事例は障害物回 避行動であるため, 判別特徵は衝突特徵, 状態遷移予測モデル も衝突しているときとしていないときの二つであるが，この原 理はより多くの状態遷移予測モデルの切り替えにも適用可能で ある。

\section{4 動作生成}

動作生成には, 強化学習問題の解法の一つであるモデル更新 型の動的計画法を用いる。制御対象は 3.1 節で得られた身体位 置とする，状態は画像座標系での身体位置であり，身体位置の 取りうる範囲で $x, y$ 軸方向にそれぞれ $N$ 分割した離散状態を $s$ とする. 画像中の離散格子の上下左右の状態に遷移する 4 パ ターンを行動 $a$ とする. 報酬は目標位置で 0 , それ以外で -1 とする, 離散状態の価值の更新には, 決定論的に状態遷移が起 こるとしたベルマン方程式を用いた。 


$$
V(s)=\max _{a}\left[R_{s s^{\prime}}^{a}+\gamma V\left(s^{\prime}\right)\right]
$$

$V(s)$ は状態 $s$ の価值, $s^{\prime}$ は遷移先の次状態を表し, 状態遷 移予測モデルにより与えられるものとする。 $\gamma$ は割引率を表し, $R$ は報酬である. また行動価值関数 $Q$ は次式で表される.

$$
Q(s, a)=\left[R_{s s^{\prime}}^{a}+\gamma V\left(s^{\prime}\right)\right]
$$

現在の身体位置を $\boldsymbol{x}(t), Q(s, a)$ から得られる目標遷移先の 離散状態 $s^{\prime}$ を身体位置に直したものを $\boldsymbol{x}_{d}$ とする. 推定した ヤコビ行列を用い，遷移後の $\boldsymbol{x}_{d}$ に最も近くなるような関節角 の変化量の組み合わせ $\Delta \boldsymbol{q}^{\left(i^{*}\right)}$ を, 次式により決定する。この ときの関節角の変化量の組み合わせは, 関節角度格子点上の現 在の格子の 8 近傍への遷移であり, $\Delta \boldsymbol{q}^{(1)}=\left[-\Delta q_{1},-\Delta q_{2}\right]^{T}$, $\Delta \boldsymbol{q}^{(2)}=\left[-\Delta q_{1}, 0\right]^{T}, \cdots, \Delta \boldsymbol{q}^{(8)}=\left[\Delta q_{1}, \Delta q_{2}\right]^{T}$ である.

$$
i^{*}=\underset{i}{\operatorname{argmin}}\left\|\boldsymbol{x}_{d}-\left\{\boldsymbol{x}(t)+\boldsymbol{J}_{q} \Delta \boldsymbol{q}^{(i)}\right\}\right\|
$$

式（11），(12）の価值更新は衝突特徴が現われて異なる状態 遷移予測モデルが選択されたとき, 状態遷移予測モデルを変更 して再計算される.

行動生成の毎時刻ステップにおいて画像に現れた特徴と衝突 特徴を比較し, 衝突特徴が存在しなければ式（7）の推定に基づ いた行動を行う。衝突特徴が存在すれば式（8）の推定に基づい て状態遷移確率を更新し, 障害物に衝突する行動はとらなくな る。このように, 特徴を基にした衝突判定を行い障害物に衝突 する度に状態遷移予測モデルを更新し，障害物回避行動を生成 する。

\section{4. 実 験 結 果}

本章では, 提案手法により得られた障害物回避行動の結果に ついて述べる.

\section{1 実験システム}

Fig. 4 のようにマニピュレータ（三菱重工社製 PA-10）が映 るようにステレオカメラを設置し, 画像を取り込む PC と運動 を生成する PC はネットワークで接続して情報を共有している. 入力の二次元画像にはステレオカメラの左眼の画像を用いる. 本実験システムでは実機による衝突実験は危険を伴うため, 事 前に $q_{1}$ を $0 \leq q_{1} \leq 50[\mathrm{deg}]$ の間で $\Delta q_{1}=5[\mathrm{deg}]$ 間隔， $q_{2}$ を $50 \leq q_{2} \leq 150[\mathrm{deg}]$ の間で $\Delta q_{2}=10[\mathrm{deg}]$ 間隔でマニピュ レータを動かした画像を撮影しておき，シミュレーションによる 実験を行った. 衝突特徴からマニピュレータと障害物の衝突を 判定する際にはステレオ処理による三次元復元座標を用い, 衝 突がおきた場合にはマニピュレータはそれ以上動かないように シミュレーションを構築している.

\section{2 身体特徵の抽出}

3.1 節で述べた身体特徵の抽出するための, 異なる画像間で の SIFT の対応点探索の結果の例を Fig. 5 に示す. SIFT マッ チングにおける閯值は $\varepsilon=2000$ とした. Fig. 5 の白い円が対 応の取れた特徵点を表し, 黒い円が対応の取れなかった特徵点 を表す。

SIFT の対応点探索により求めた特徵点の位置と変位量を用

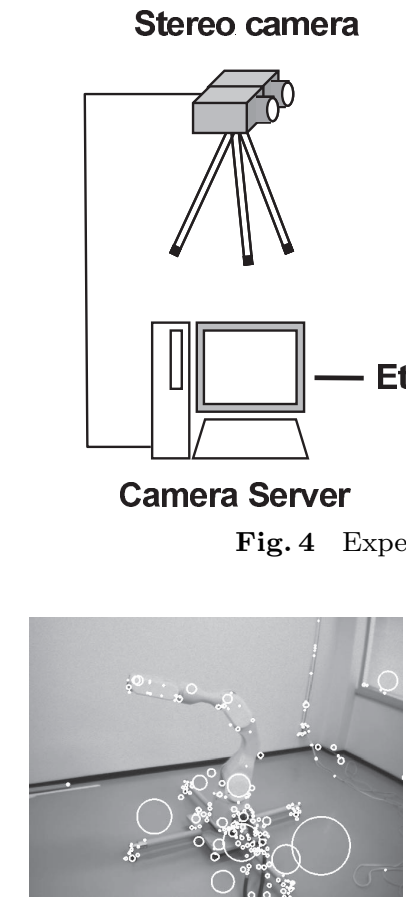

(a) before motor command

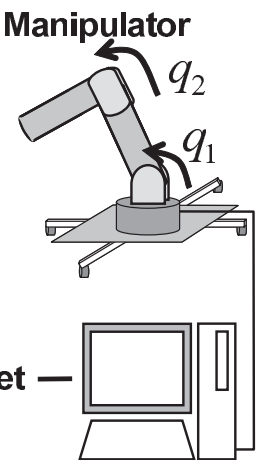

Motion Controller
Fig. 5 Example of matching of SIFT features

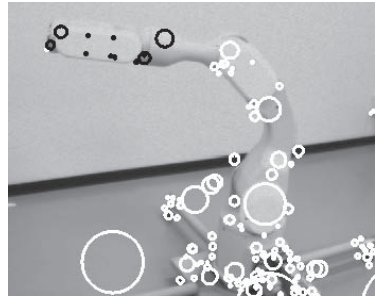

(a) example1

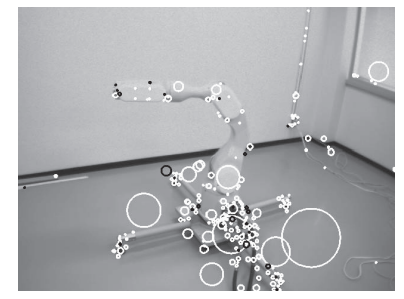

(b) after motor command

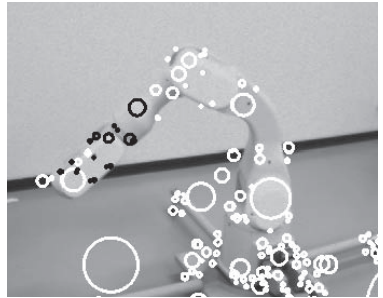

(b) example2
Fig. 6 Example of extraction of body relevant feature

い, mean shift によるクラスタリングによって抽出した身体特 徵の結果の例を Fig. 6 に示す. 身体特徴として抽出された特徵 点を黒い円で示す. 同様の処理を, 収集した全パターンの基準 姿勢に対し， $q_{1}$ を $\pm 5[\mathrm{deg}], q_{2}$ を $\pm 10[\mathrm{deg}]$ 変位させた 4 と おりの変化をさせて行う。

画像中での手先リンクの大きさは約 $120 \times 35$ [pixel], 身体特 徵として抽出されたクラスタの大きさは約 $110 \times 30$ [pixel] で あった．全 116 姿勢に対して身体特徽抽出を行ったところ，す ベての姿勢で抽出した身体特徵の重心位置が手先のリンク周辺 に存在した。 105 姿勢 $(90.5 \%)$ では，身体位置は手先リンク のなかの約 $60 \times 30$ [pixel] の間の範囲に存在し，身体特徴のク ラスタの大きさと同程度の規模のばらつきで身体特徵が抽出で きた。

\section{3 衝突特徵の選択}

衝突特徵の選択はFig. 7 のような画像を用いて行う。黒い円 は衝突により現れた特徴点を表し, 白い円が対応の取れた特徴 点, 黒い四角は未対応特徵集合 $A$ の特徵点とマッチングの取れ 


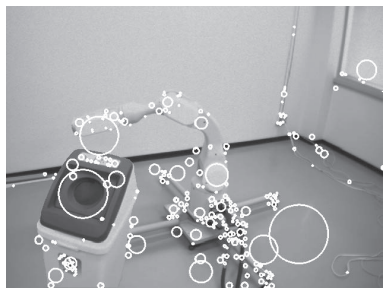

(a) before motor command

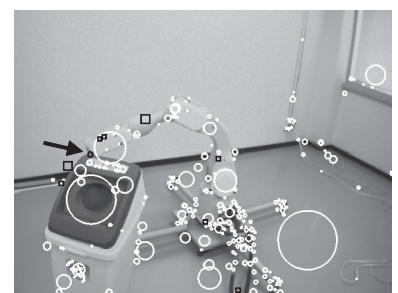

(b) after motor command
Fig. 7 Example of selection of collision relevant features

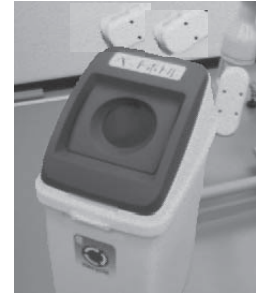

(a) patterns of collision

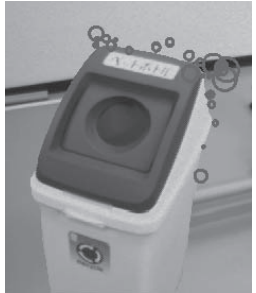

(b) all collision relevant features
Fig. 8 All selected collision relevant features

Table 1 Evaluation of collision detection

\begin{tabular}{|c|cc|cc|}
\hline & Collision & {$[\%]$} & No collision & {$[\%]$} \\
\hline $\begin{array}{c}\text { Recognized as } \\
\text { collision }\end{array}$ & $15 / 21$ & {$[71.4]$} & $4 / 273$ & {$[1.5]$} \\
\hline $\begin{array}{c}\text { Recognized as } \\
\text { no collision }\end{array}$ & $6 / 21$ & {$[28.6]$} & $269 / 273$ & {$[98.5]$} \\
\hline
\end{tabular}

た特徽点を表している. Fig. 7 (b) の矢印の指し示す黒い円のよ うな，障害物との衝突によって現れた特徴点を抽出する.

Fig. 8 に選択された衝突特徴を示す. Fig. 8 (a) に様々な姿勢 でマニピュレータが障害物に衝突している例を示す. 衝突特徴 はマニピュレータと障害物の接近している部分の周辺に現れて いることが分かる (Fig. 8(b)).

障害物を衝突特徵選択時と比べて実空間で画面内の左方向に $200[\mathrm{~mm}]$ 移動させたときの衝突特徴検出の評価を行った．様々 な姿勢で行動したときの衝突判定の評価を Table 1 に示す. 全 部で 294 パターンあり, そのうち実際に障害物と衝突している のは 21 パターンあった. 21 パターンの衝突に対し, 衝突特徴 を検出できたのは 15 パターン $(71.4 \%)$ であった. 一方, 衝突 していないときに衝突なしと判断されたのは $98.5 \%$ であった. 衝突のないときは非常に高い確率で正しく判定されている.

\section{4 障害物回避行動}

障害物の存在しないときのリーチングの結果を Fig. 9 に示 す.図中の円は身体位置を表し, 四角が目標位置を表す. 行動す るときのマニピュレータの関節角の変化量は $\Delta q_{1}= \pm 5[\mathrm{deg}]$, $\Delta q_{2}= \pm 10[\mathrm{deg}]$ である. 状態は身体位置の取りうる範囲で $x, y$ 軸方向にそれぞれ $N=10$ で分割した離散状態を扱う. 割引率 $\gamma$ は 0.95 とした. 報酬 $R$ はゴールで 0 , それ以外の状態で -1 とした.リーチングでは 8 ステップで目標位置に到達した.

障害物が存在するときの障害物回避行動の結果を Fig. 10 に 示す.このとき Table 1 の評価時と同様に, 障害物を衝突特徴 選択時と比べて実空間で画面内の左方向に $200[\mathrm{~mm}]$ 移動させ

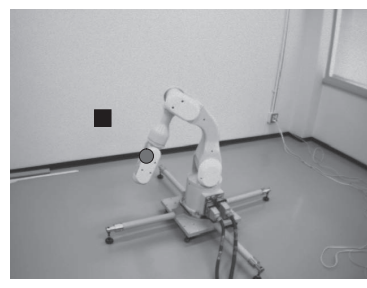

(1)

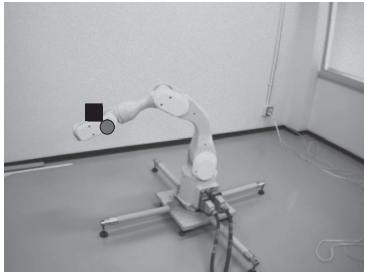

(3)

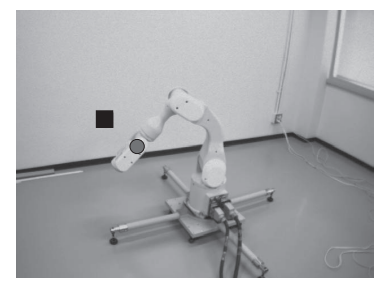

(2)

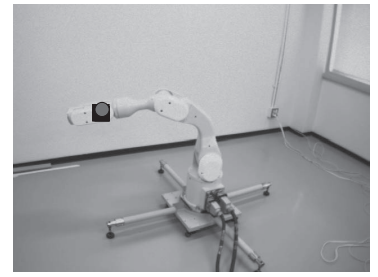

(4)
Fig. 9 Result of reaching

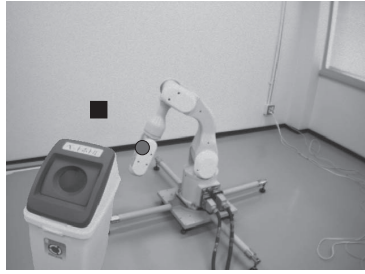

(1)

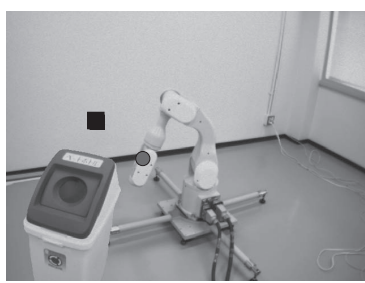

(3)

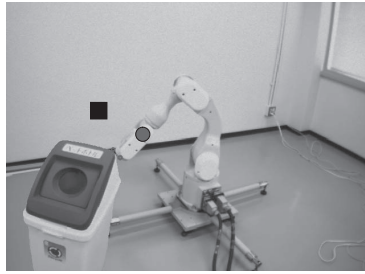

(5)

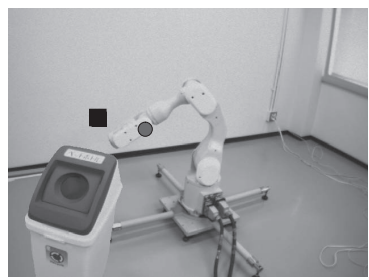

(7)

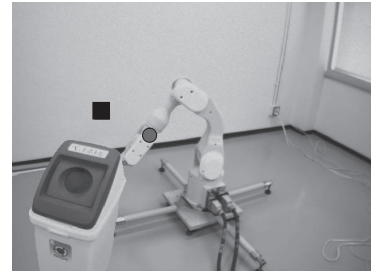

(2)

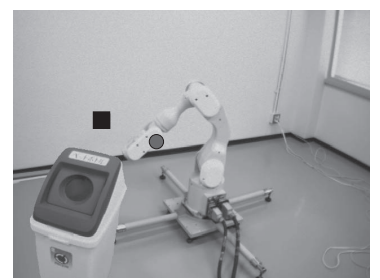

(4)

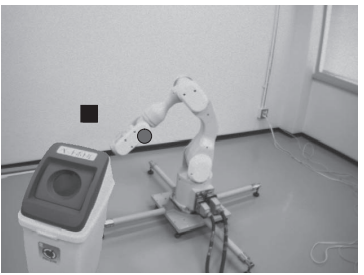

(6)

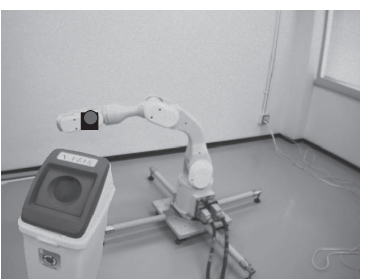

(8)
Fig. 10 Result of avoidance obstacles

ている．障害物回避行動ではゴールするまでに 21 ステップか かり, 衝突特徴を 4 回検出した.

Fig. 9 と Fig. 10 の 2 回の実験では, 初期姿勢と目標位置を同 


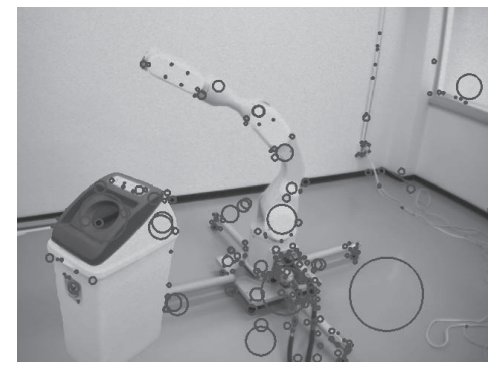

Fig. 11 Obstacle with different posture1

Table 2 Evaluation of collision detection with different orientation 1

\begin{tabular}{|c|cc|cc|}
\hline & Collision & {$[\%]$} & No collision & {$[\%]$} \\
\hline $\begin{array}{c}\text { Recognized as } \\
\text { collision }\end{array}$ & $13 / 24$ & {$[54.2]$} & $14 / 221$ & {$[6.3]$} \\
\hline $\begin{array}{c}\text { Recognized as } \\
\text { no collision }\end{array}$ & $11 / 24$ & {$[45.8]$} & $207 / 221$ & {$[93.7]$} \\
\hline
\end{tabular}

Table 3 Evaluation of collision detection with different orientation 2

\begin{tabular}{|c|cc|cc|}
\hline & Collision & {$[\%]$} & No collision & {$[\%]$} \\
\hline $\begin{array}{c}\text { Recognized as } \\
\text { collision }\end{array}$ & $18 / 25$ & {$[72.0]$} & $8 / 267$ & {$[3.0]$} \\
\hline $\begin{array}{c}\text { Recognized as } \\
\text { no collision }\end{array}$ & $7 / 25$ & {$[28.0]$} & $259 / 267$ & {$[97.0]$} \\
\hline
\end{tabular}

様に設定しており，障害物を回避している様子が分かる. Fig. 9 中には障害物が存在しないため, マニピュレータが初期姿勢から 目標位置に向かって直線的に動作している. それに対して Fig. 10 では障害物を設置しているため, Fig. 9 のように動作すると障 害物に衝突してしまう。衝突特徴が現れ障害物に衝突している と判定されたら，そのときにとった衝突する行動をとらないよ うに学習し, 障害物を避けて目標位置に到達している。ゴール 時の身体位置と目標位置には誤差があるが，これはゴールの格 子内に身体位置が存在したら行動を終了するようにしているた めである、また, 衝突特徴選択時と障害物回避行動時で障害物 の位置を異なる位置に設置したことにより, 学習時と設定が異 なっていても動作することを確認した.

\section{5 障害物を変更した場合の衝突特徵}

選択した衝突特徴の汎用性を評価するために，障害物を变更 した場合の評価実験を行った。すべての場合の衝突の検出は, 4.3 節で選択された (Fig. 8 (b) で示される) 衝突特徴を用いて 行う.

\subsection{1 障害物の向きを変更した場合}

選択した衝突特徴がある程度設定が異なっても検出できるか を確認するために, 障害物の向きを変更して衝突判定の評価を 行った（Fig. 11）. 障害物の向きを変更して衝突判定の評価を 行った結果を Table 2 に示す. 衝突特徴の検出率は $54.2 \%$ で あったままた，障害物の向きを変更してマニピュレータから遠 ざけて（学習時より $400[\mathrm{~mm}]$ 移動）設置し, 衝突判定の評価 を行った結果を Table 3 に示す。衝突特徴の検出率は $72.0 \%$ と, 障害物の向きを変更しても, 変更しないときと同等の検出 率を得ることができた。これらの結果より, 障害物の向きを変

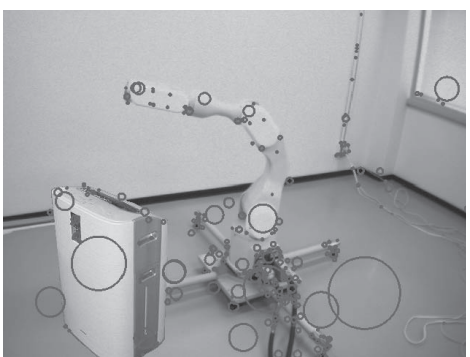

Fig. 12 Collision detection with different obstacle 1

Table 4 Evaluation of collision detection with different obstacle 1

\begin{tabular}{|c|cc|cc|}
\hline & Collision & {$[\%]$} & No collision & {$[\%]$} \\
\hline $\begin{array}{c}\text { Recognized as } \\
\text { collision }\end{array}$ & $14 / 22$ & {$[63.6]$} & $0 / 282$ & {$[0.0]$} \\
\hline $\begin{array}{c}\text { Recognized as } \\
\text { no collision }\end{array}$ & $8 / 22$ & {$[36.4]$} & $282 / 282$ & {$[100.0]$} \\
\hline
\end{tabular}

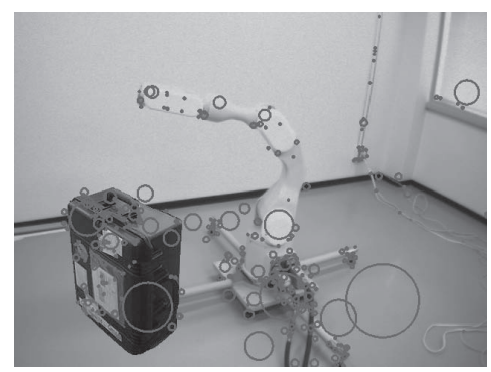

Fig. 13 Collision detection with different obstacle 2

Table 5 Evaluation of collision detection with different obstacle 2

\begin{tabular}{|c|cc|cc|}
\hline & Collision & {$[\%]$} & No collision & {$[\%]$} \\
\hline $\begin{array}{c}\text { Recognized as } \\
\text { collision }\end{array}$ & $17 / 28$ & {$[60.7]$} & $15 / 268$ & {$[5.6]$} \\
\hline $\begin{array}{c}\text { Recognized as } \\
\text { no collision }\end{array}$ & $11 / 28$ & {$[39.3]$} & $253 / 268$ & {$[94.4]$} \\
\hline
\end{tabular}

更してもある程度の検出が可能であるといえる.

\subsection{2 障害物自体を変更した場合}

選択した衝突特徴にどのくらいの汎用性があるかを評価するた めに，障害物自体を変更したときの評価を行う。まず，Fig. 12 に示すような，学習時に用いた障害物と近い濃淡值をもつ障害 物を用いて評価を行った. Fig. 12 のように障害物を設置し, 衝 突判定の評価を行った結果を Table 4 に示す. 衝突特徴の検出 率は $63.6 \%$ でった。

次に, Fig. 13 に示すような，学習時に用いた障害物と濃淡 值の近くない障害物を用いて評価を行った. Fig. 13 のように障 害物を設置し, 衝突判定の評価を行った結果を Table 5 に示 す. 衝突特徵の検出率は $60.7 \%$ であった。

\section{6 考察}

\subsection{1 障害物回避行動}

Fig. 10 では障害物回避行動に成功したが，失敗する場合もあ る.この問題として, 衝突特徴の検出率の低さが挙げられる. 衝 突特徴選択時に身体と障害物の衝突を距離画像によって判定し ているが，距離画像はノイズが多く不安定なため，衝突をすべ 
Table 6 Success rate of SIFT matching

\begin{tabular}{|c|c|c|}
\hline Feature & Ave. \# of features & Percentage[\%] \\
\hline All & 17.0 & \\
\hline Success & 10.0 & 58.8 \\
\hline Failure 1 & 4.2 & 24.7 \\
\hline Failure 2 & 2.8 & 16.5 \\
\hline
\end{tabular}

て正しく判定できたわけではない. 衝突していると判定された ときのみ衝突特徴を選択しているため, 二次元画像では障害物 に衝突していても距離画像による判定で衝突していないと判定 された場合は，そのとき現れた衝突特徴の選択を行わない。こ のような距離画像の判定の誤りにより, 衝突特徴の収集が不十 分であったと考えられる. しかしこの問題は力覚センサなどを 用いた物理的な接触により衝突判定を行う場合には生じないた め，実機に実装するときには問題にならないと考えられる。

衝突特徵の検出率の低さのほかに障害物回避行動に失敗する 問題として, 状態遷移予測モデルの不安定な生成が考えられる. 状態遷移予測モデルの生成には, 身体特徵の変位量を用いてい るが, SIFT マッチング時に誤対応を取ると運動による変位と は異なる変位量が得られてしまう. SIFT マッチングの誤対応に よる影響を評価するために, SIFT マッチングの誤対応がどの 程度生じているのかを調べた。手先部分における SIFT マッチ ングの 5 パターンの平均結果を Table 6 に示す. Failure 1 は 対応の取れなかった特徴数を表している。 また Failure 2 は誤対 応を取った特徵数を表している。この結果より，SIFTマッチン グに成功した割合に対して䛊対応を取った割合が高いため, 誤 対応を取った特徵点の変位量が身体特徵の変位量に影響してい ることが分かる.さらにマッチング性能のよい特徵抽出手法を 用いることにより, 安定した状態遷移予測モデルを生成するこ とができ, 障害物回避行動の成功率が上がることが期待される。

\subsection{2 障害物の設定による衝突検出率}

障害物の位置を衝突特徵選択時から変更した場合の衝突特徽 の検出率は, $71.4 \%, 73.7 \%$ でった。このことより, 衝突特徵 選択時と同じ障害物を設置したときは，位置を変更しても $70.0 \%$ を超える検出率が得られることを確認した。

また，向きを変更した障害物については， $54.2 \%$ （衝突特徴 選択時から $200[\mathrm{~mm}]$ 移動した位置), $72.0 \%$ (衝突特徵選択時 から $400[\mathrm{~mm}]$ 移動した位置) であった。この結果より, 障害 物の向きを変更してもある程度の衝突を検出できることが確認 できたが，障害物をマニピュレータから遠ざけたほうが検出率 が高かった。この原因は, 衝突特徵選択時の学習パターンにあ ると考えられる。学習時に適切な衝突特徵を十分に選択できて いるかどうかが, 衝突特徽の検出率にかかわっていると考えら れる。障害物の位置を変化させることで，十分に経験していな い方向からの衝突が生じる（逆に十分に経験していない方向か らの衝突が生じなくなる）ために衝突検出率が変化すると考え られる. Fig. 14 の破線内で障害物と衝突するパターンは多数 存在するが, 実線内で障害物と衝突するパターンは少なかった. そのため, Fig. 14 の実線内で障害物と衝突するときの衝突検出 率が低くなっている。障害物をマニピュレータから遠ざけたと きに衝突検出率が上がるのは，障害物を遠くに設置することで,

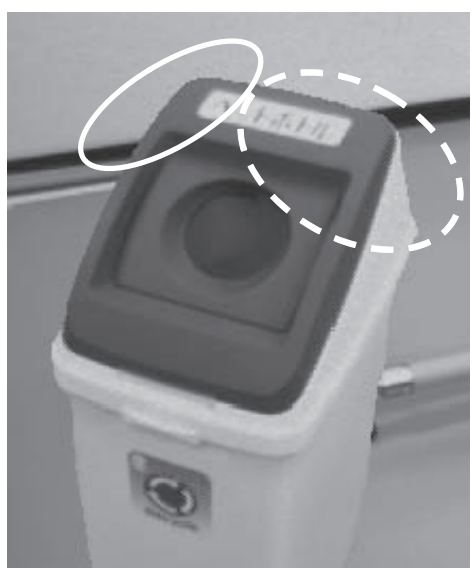

Fig. 14 Position of collision with obstacle

Fig. 14 の実線内での障害物との衝突回数が少なくなるためだと 考えられる. それに対して, Fig. 14 の破線内での衝突はほぼ検 出できることを確認した。

また, 衝突特徵選択時の障害物と近い濃淡值をもつ障害物を 設置した場合では, 衝突特徴検出率は $63.6 \%$ であった。また, 衝突特徴選択時の障害物と濃淡値の近くない障害物を設置した 場合では，衝突特徴検出率は $60.7 \%$ であった。これらの結果よ り，障害物自体を変更しても， $60.0 \%$ を超える検出率が得られ ることを確認した。このことより, 衝突特徴の検出率には障害 物の濃淡值よりも，障害物との相対的な姿勢が影響しているこ とが考えられ，選択した衝突特徽は障害物に対する沉用性をあ る程度持っているといえる。

SIFT 特徵量は DoG 画像の極值を用いて検出されるため, 障 害物とマニピュレータの位置関係が現れる特徴に影響する。本 実験ではマニピュレータの動作を $q_{1}$ について $5[\mathrm{deg}], q_{2}$ につ いて $10[\mathrm{deg}]$ という離散幅で行っているため, 障害物の設置位 置によって衝突の仕方に違いが生じる。この違いが衝突特徴の 検出に悪影響を与えていることが考えられる。離散的な動作を 行うシミュレーションではなく, 連続的に動作させながら衝突 により停止する実機実験であれば，このような離散幅の影響に よる衝突特徴のばらつきがなくせるため, より衝突特徴をロバ ストに検出できるようになると考えられる。ささらに，障害物の 種類 - 位置以外の環境変化の例としては背景の変化も考えられ るが, SIFT 特徵量はキーポイント周辺領域の持つ勾配情報で 記述されるため, 背景が大きく変わったときは特徵検出性能が 低下すると考えられる。

\section{5. 今後の課 題}

吉川らは画像中の自己身体と環境を確率分布で推定すること によってそれらを分離する手法を提案している [24]. 本手法に も確率を取り入れることで, 閾値処理などによらずに必要な情 報を抽出することが期待できる. また, 衝突特徵の抽出率を上 げるためにはノイズを記憶していく必要があると考えられるが すべてのノイズを記憶していくことは現実的ではないため，， イズも確率的に扱うことで, より一般性を持った汎化能力の高 い手法に拡張できると考えられる。 
現在の手法では，マニピュレータがオクルージョンにより見 えなくなるような場合に対応することはできない.これに対応 する方法としては, ロボットに奥行き方向の知覚を与え, 腕部 の奥行きに応じてオクルージョンが生じる場合, 生じない場合 双方の経験をさせることでその区別を可能にするように提案手 法を拡張することが考えられる. さらに, オクルージョンが生 じても手先位置が仮想的に推定できる補外などを備えることが 考えられる.

また，現在の方法では衝突が起きてからモデルの切り替えを 行っている，学習前には「接触した状態からさらに腕を動かそう として動けない」ことで衝突を知覚していたのに対して, 動作 生成時には「接触した状態の画像を見る」だけでこれ以上動け ないことが判断できるという意味では, 動作生成のための有用 性は最低限得られているといえる。しかし, より滑らかな衝突 回避動作を生成するためには，マニピュレータが障害物に衝突 する前にモデルを切り替えて衝突せずに動作することが望まし い. 系の挙動が切り替わる瞬間のみに着目したモデルの切り替 えではなく, 挙動が切り替わる状態へと遷移する時系列を考慮 した特徵の検出を行えるように提案手法を拡張することで，こ のような問題に対処することが考えられる. 衝突の瞬間よりも 前の状況を表す特徴を選択できれば，より安全な回避動作が実 現できると考えられる.

本実験では手先の抽出のみを行ったが，より複雑なシステム やタスクを想定すると, 手先のリンクだけでなく他のリンクも 発見しそれらを区別して扱えるようにできることが望ましい. Sturm らは, ベイジアンネットワークを用いてマーカーにより 抽出されたマニピュレータの各リンクの位置・姿勢の依存関係 を発見する手法を提案している [25]. この研究のように, 各関 節の運動に対する視覚特徵の動き方の違いを関数近似などを通 じて識別することで, 本研究で提案する身体の発見をさらに拡 張し, 手先以外のリンクの発見やリンク間の依存関係を発見す ることが可能であると考えられる.

さらに，提案手法を汎用的なロボットに拡張するためには障 害物回避行動だけではなく様々な夕スクを考え, 行動に応じて 獲得するべき特徴を自律的に選択する必要がある。例えば，対 象物との接触の仕方によって対象物の動き方が異なるような対 象物操作問題において, 望ましい動きを実現するように接触す るような行動を生成することなどが考えられる。

\section{6. おわりに}

本論文では，画像から SIFTを用いてボトムアップに必要な 特徵を抽出し, 2 関節マニピュレータの障害物回避行動を行っ た. 身体を表す特徵を自律的に発見し，身体の状態遷移予測モ デル，障害物との衝突を表す特徴を選択した。障害物回避行動 には強化学習の一つである動的計画法を用い，オンラインで状 態遷移確率を更新することにより障害物回避行動を達成した。 今回は簡単な障害物回避行動を扱っているため, 判別特徴は衝 突特徴, 状態遷移予測モデルも衝突しているときとしていない ときの二つだが，この枠組みはそれ以上のモデルにも拡張可能 である。より高精度な識別を行うと同時に，異なる夕スクへも 適用していくことが今後の課題である.

\section{参 考 文 献}

[1] 池内克史：“画像による実物体のモデルの作成”, 日本ロボット学会誌, vol.16, no.6, pp.763-766, 1998.

[2] 金広文男, 吉見隆, 梶田秀司, 森澤光晴, 金子健二, 比留川博久, 富 田文明：“3D グリッドマップを用いたヒューマノイドの狭监部移動”, 日本ロボット学会誌, vol.25, no.4, pp.589-597, 2007.

[3] 岡田慧, 小島光晴, 稲葉雅幸: “認識行動共有知識ベースシステムにお ける複数視覚特徵統合による物体認識”, 日本ロボット学会誌, vol.26, no.6, pp.537-545, 2008.

[4] カール・マクドーマン：“感覚一運動統合による記号接地”, 日本口 ボット学会誌, vol.17, no.1, pp.20-24, 1999.

[ 5 ] 浅田稔: “運動学習から行動学習・認知発達へ”, 日本ロボット学会誌, vol.22, no.2, pp.150-155, 2004

[6] 國吉康夫： “自律適応創発システム”, 日本ロボット学会誌, vol.26, no.7, pp.744-745, 2008

[ 7 ] T. Minato and M. Asada: "Towards Selective Attention: Generating Image Features by Learning a Visuo-Motor Map," Robotics and Autonomous Systems, vol.45, pp.211-221, 2003.

[8] P. Fitzpatrick, G. Metta, L. Natalc, S. Rao and G. Sandini: "Learning about objects through action - initial steps towards artificial cognition," Proc. of IEEE International Conference on Robotics and Automation, pp.3140-3145, 2003.

[9] A. Stoytchev: "Toward Video-Guided Robot Behaviors," Proceedings of the 7th International Conference on Epigenetic Robotics. pp.165-172, 2007.

[10] A.K. McCallum: "Instance-based utile distinctions for reinforcement learning with hidden state," Proceedings of the 12th International Machine Learning Conference, 1995.

[11] A.K. McCallum: "Learning to use selective attention and short-term memory in sequential tasks," Proceedings of the 4th International Conference on Simulation of Adaptive Behavior:From Animals to Animats 4, pp.315-324, 1996.

[12] H. Ishiguro, R. Sato and T. Ishida: "Robot oriented state space construction," Proceedings of the 1996 IEEE/RSJ International Conference on Intelligent Robots and Systems, pp.14961501,1996

[13] 高橋泰岳, 浅田稔： “実ロボットによる行動学習のための状態空間の漸 次的構成”, 日本ロボット学会誌, vol.17, no.1, pp.118-124, 1999.

[14] D.M. Wolpert and M. Kawato: "Multiple paired forward and inverse models for motor control," Neural Networks, vol.11, pp.1317-1329, 1998.

[15] M. Haruno, D.M. Wolpert and M. Kawato: "Mosaic model for sensorimotor learning and control," Neural Computation, vol.13, pp.2201-2220, 2002.

[16] 鮫島和行，銅谷賢治，川人光男：“強化学習 MOSAIC：予測性によ るシンボル化と見まね学習”, 日本ロボット学会誌, vol.19, no.5, pp.551-556, 2001.

[17] D.G. Lowe: "Object Recognition from Local Scale-Invariant Features," Proc. of IEEE International Conference on Computer Vision, pp.1150-1157, 1999.

[18] T. Asfour, K. Regenstein, P. Azad, J. Schroder, A. Bierbaum, N. Vahrenkamp and R. Dillmann: "ARMAR-III: An integrated humanoid platform for sensory-motor control," Proc. of the IEEERAS/RSJ Int. Conf. on Humanoid Robots, pp.169-175, 2006.

[19] A. Chavez and H. Raposo: "Robot Path Planning Using SIFT and Sonar Sensor Fusion," Proceedings of the 7th WSEAS International Conference on Robotics, Control \& Manufacturing Technology, pp.251-256, 2007.

[20] L. Itti, C. Koch and E. Niebur: "A Model of Saliency-Based Visual Attention for Rapid Scene Analysis," IEEE Transactios on Pattern Analysis and Machine Intelligence, vol.20, no.11, pp.1254-1259, 1998.

[21] R.S. Sutton: Reinforcement learning. MIT Press, 1998.

[22] J.C. Latombe: Robot Motion Planning. Kluwer Academic Pub- 
lishers, 1991

[23] D. Comaniciu and P. Meer: "Mean Shift: A Robust Approach toward Feature Space Analysis," IEEE Trans. Pattern Anal. Machine Intell., vol.24, no.5, pp.603-619, 2002.

[24] 吉川雄一郎, 細田耕, 浅田稔, 辻義樹：“複数センサ データの不変性に
基づく身体の発見”, 日本ロボット学会誌, vol.23, no.8, pp.986-992, 2005.

[25] J. Sturm, C. Plagemann and W. Burgard: "Adaptive body scheme models for robust robotic manipulation," Proc. of the Robotics: Science and Systems, 2008.

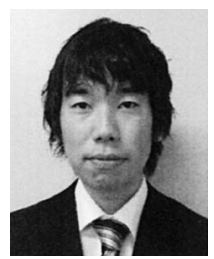

岡本太一（Taichi Okamoto）

2008 年東京農工大学工学部電気電子工学科卒業, 2010 年同大学大学院電気電子工学専攻博士前期課 程修了. 2010 年 4 月（株）オ八ラ入社.

(日本ロボット学会学生会員)

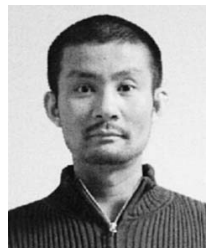

\section{大西正輝（Masaki Onishi）}

1997 年大阪府立大学工学部情報工学科卒業. 2002 年同大学大学院博士後期課程修了. 同年理化学研究 所バイオ・ミメテイックコントロール研究センター 研究員を経て, 2006 年産業技術総合研究所情報技 術研究部門研究員, 現在に至る. 理化学研究所客員 研究員.ロボットの認知・知識処理に関する研究に 従事. 電子情報通信学会, 電気学会, 映像情報メディア学会各会員. 工学博士.
(日本ロボット学会正会員)

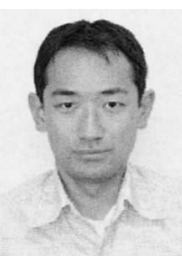

小林祐一（Yuichi Kobayashi）

1997 年東京大学工学部精密機械工学科卒業, 1999 年同大学大学院工学系研究科精密機械工学専攻修了. 2002 年同博士課程修了, 博士 (工学). 同年理化学 研究所バイオ・ミメティックコントロール研究セン 夕ー研究員. 2007 年より東京農工大学共生科学技 術院特任准教授, 理化学研究所客員研究員. ロボッ 卜学習と自律分散システムの研究に従事.（日本ロボット学会正会員） 